\title{
Nimesulide inhibits proliferation and induces apoptosis of pancreatic cancer cells by enhancing expression of PTEN
}

\author{
MEIFEN CHU ${ }^{1}$, TONGTONG WANG ${ }^{2}$, AIHUA SUN $^{1}$ and YU CHEN ${ }^{1}$ \\ ${ }^{1}$ College of Laboratory Medicine, Hangzhou Medical College; ${ }^{2}$ The Second Clinical Medical College, \\ Zhejiang Chinese Medical University, Hangzhou, Zhejiang 310053, P.R. China
}

Received August 24, 2017; Accepted January 5, 2018

DOI: $10.3892 /$ etm.2018.6191

\begin{abstract}
Pancreatic cancer is the fourth leading cause of cancer-associated cases of mortality worldwide. Prostaglandin-endoperoxide synthase 2 (COX-2) is considered a therapeutic target for prevention of pancreatic cancer. Nimesulide, a selective COX-2 inhibitor, can induce cell apoptosis, resulting in an anti-cancer effect. However, the mechanism underlying this effect remains to be elucidated. The present study aimed to evaluate the effects of nimesulide on proliferation of PANC-1 cells using an MTT assay. Apoptosis was evaluated by DNA laddering and Annexin V-fluorescein isothiocyanate/propidium iodide-stained flow cytometry. Furthermore, western blot analysis was used to elucidate the mechanism underlying nimesulide treatment in PANC-1 cells. It was determined that proliferation of PANC-1 cells was inhibited by nimesulide in a dose-dependent manner. Nimesulide promoted apoptosis of PANC-1 cells. Western blot analysis demonstrated that nimesulide increased expression of cleaved caspase- 3 and apoptosis regulator $\mathrm{Bax}(\mathrm{Bcl}-2$ associated protein $\mathrm{X}$ ), and decreased the expression of pro-caspase- 3 and apoptosis regulator Bcl-2 (B-cell lymphoma 2). Furthermore, nimesulide enhanced expression of phosphatase and tensin homolog (PTEN), and decreased the expression level of COX-2 and vascular endothelial growth factor. In summary, the results of the present study demonstrated that nimesulide could induce apoptosis and inhibit growth of PANC-1 cells by enhancing the expression of PTEN, which indicates the potential of nimesulide to prevent tumor angiogenesis.
\end{abstract}

Correspondence to: Dr Yu Chen, College of Laboratory Medicine, Hangzhou Medical College, 481 Binwen Road, Hangzhou, Zhejiang 310053, P.R. China

E-mail: cheny1124@163.com

Key words: nimesulide, pancreatic cancer cells, proliferation, apoptosis, prostaglandin-endoperoxide synthase 2, phosphatase and tensin homolog

\section{Introduction}

Pancreatic cancer is one of the most common human gastrointestinal malignancies and the fourth leading cause of cancer-associated cases of mortality worldwide (1). In China, morbidity of pancreatic cancer ranks seventh among malignancies and pancreatic cancer is the sixth leading cause of mortality among all cancer types (2). Furthermore, the incidence of pancreatic cancer has demonstrated an upward trend in recent years (3). Primary characteristics of pancreatic cancer include late diagnosis, strong local invasion, early metastasis, high mortality rate, poor prognosis and low long-term survival (4). Compared with other common treatments, including chemotherapy, radiotherapy and biological therapy (5-7), surgical excision is considered the most effective option at present, but only $10-15 \%$ of patients undergo complete tumor resection (8). Despite the available therapies, the 5-year survival rate is $\sim 5 \%$ (8). In addition, within 7 years following surgery of pancreatic cancer the mortality rate among patients is $\sim 100 \%(9,10)$. Therefore, it is necessary to develop a more effective treatment for pancreatic cancer.

As previously demonstrated, overexpression of the prostaglandin-endoperoxide synthase 2 (COX-2) gene may be associated with tumorigenesis and progression of breast, prostate and lung cancer (11-13). Furthermore, COX-2 is considered a therapeutic target for prevention of pancreatic cancer $(14,15)$. Nimesulide is a selective COX-2 inhibitor that could delay the progression of pancreatic cancer precursor lesions, inhibit cell proliferation and induce apoptosis (16-18). Phosphatase and tensin homolog (PTEN) is a lipid phosphatase that serves a role in tumor suppression (19). However, the effect of COX-2 inhibitors on PTEN in the context of pancreatic cancer remains to be elucidated.

In the present study, the effects of nimesulide on proliferation and apoptosis of pancreatic cancer cells were investigated with the aim of elucidating the potential PTEN-associated effect of nimesulide on pancreatic cancer.

\section{Materials and methods}

Reagents and cell culture. Nimesulide was purchased from Sigma-Aldrich (Merck KGaA, Darmstadt, Germany). Dimethyl sulfoxide (DMSO), MTT and Annexin V/Dead Cell Apoptosis kit were purchased from Hangzhou Multi 
Sciences Biotech Co., Ltd. (Hangzhou, China). Primary antibodies at a dilution of 1:1,000 against cleaved-caspase-3 (cat. no. AC033), pro-caspase-3 (cat. no. AF1261), PTEN (cat. no. AF1426), COX-2 (cat. no. AF1924) and vascular endothelial growth factor (VEGF; cat. no. AF1309), Bcl-2 (cat. no. AB112), Bcl-2 associated protein X (Bax; cat. no. AB026) and $\beta$-actin (cat. no. AA128) were utilized in the present study. The following secondary antibodies (Horseradish peroxidase conjugated Goat Anti-Rabbit Immunoglobulin G, 1:5,000; cat. no. A0208; Horseradish peroxidase conjugated Goat Anti-Mouse immunoglobulin G; 1:5,000; cat. no. A0216) were also utilized. All antibodies were supplied by Beyotime Institute of Biotechnology (Haimen, China) Human pancreatic cancer cell line PANC-1 was obtained from the Type Culture Collection of the Chinese Academy of Sciences (Shanghai, China). The cells were cultured in Dulbecco's modified Eagle's medium (DMEM) with $10 \%$ fetal bovine serum (FBS), $100 \mathrm{U} / \mathrm{ml}$ penicillin and $100 \mu \mathrm{g} / \mathrm{ml}$ streptomycin in a humidified atmosphere at $37^{\circ} \mathrm{C}$ with $5 \% \mathrm{CO}_{2}$. DMEM, FBS and $0.25 \%$ Trypsin-EDTA were purchased from Gibco (Thermo Fisher Scientific, Inc., Waltham, MA, USA).

Cell proliferation assay. Viability of PANC-1 cells following treatment with nimesulide was evaluated using an MTT assay, as previously described (20). Briefly, $5 \times 10^{3}$ cells/well $(100 \mu \mathrm{l})$ were seeded in 96-well plates with different concentrations of nimesulide $(0,25,50,100,200$ and $400 \mu \mathrm{mol} / \mathrm{l})$. DMSO was used as the control treatment. Following incubation at $37^{\circ} \mathrm{C}$ for $48 \mathrm{~h}, 20 \mu \mathrm{l}$ MTT ( $5 \mathrm{mg} / \mathrm{ml}$ ) was added to each well followed by incubation at $37^{\circ} \mathrm{C}$ for $4 \mathrm{~h}$. DMSO was utilized to dissolve the purple formazan and the absorbance was measured at a wavelength of $490 \mathrm{~nm}$ using a microplate reader (Synergy HTX; BioTek Instruments, Inc., Winooski, VT, USA). The results are expressed as inhibition rates according to the following formula: Inhibition rate $(\%)=1-(\mathrm{OD}$ treatment-OD blank)/(OD control-OD blank) x100\%.

DNA laddering analysis. Cells were collected following treatment with different concentrations of nimesulide at $37^{\circ} \mathrm{C}$ for $48 \mathrm{~h}$. The supernatant was discarded following centrifugation at a speed of $1,000 \mathrm{x} \mathrm{g}$ for $5 \mathrm{~min}$ at room temperature and the pellet was washed with PBS (0.01 M, pH 7.4). Cells were incubated with $500 \mu 1$ lysis buffer [0.5 M Tris-HCl (pH 8.0), $0.02 \mathrm{mmol} / 1 \mathrm{EDTA}$ and $1 \% \mathrm{NP}-40]$ in a water bath at $55^{\circ} \mathrm{C}$ for $16 \mathrm{~h}$. The solutions were centrifuged at a speed of $12,000 \mathrm{x} \mathrm{g}$ for $5 \mathrm{~min}$ at $4^{\circ} \mathrm{C}$ and treated with RNase A (final concentration, $20 \mathrm{mg} / 1$; cat. no. R6148; Sigma-Aldrich) with 1\% SDS and proteinase $\mathrm{K}$ (final concentration, $20 \mathrm{mg} / \mathrm{l}$; cat. no. P2308; Sigma-Aldrich). A total of $60 \mu 13 \mathrm{M}$ sodium acetate and $600 \mu \mathrm{l}$ ice-cold absolute ethanol was added, and samples were incubated at $-20^{\circ} \mathrm{C}$ for at least $1 \mathrm{~h}$, followed by centrifugation at a speed of $12,000 \mathrm{x} \mathrm{g}$ for $20 \mathrm{~min}$ at $4^{\circ} \mathrm{C}$. Resulting DNA pellets were dissolved in TE buffer $(10 \mathrm{mM}$ Tris-HCl, $1 \mathrm{mM}$ EDTA at $\mathrm{pH}$ 7.4) and the DNA ladder was separated by electrophoresis on a $2 \%$ agarose gel (21).

Apoptosis assay. Apoptosis of PANC-1 cells were detected using the aforementioned Annexin V/propidium iodide (PI) Apoptosis Detection kit. Briefly, cells were exposed to various concentrations $(50,100,200$ and $400 \mu \mathrm{mol} / \mathrm{l})$ of nimesulide
Table I. Nimesulide inhibits proliferation of PANC-1 cells $(n=3)$.

\begin{tabular}{ccc}
\hline Nimesulide $(\mu \mathrm{mol} / \mathrm{l})$ & Absorbance & Inhibition rate $(\%)$ \\
\hline 0 & $1.046 \pm 0.032$ & 0 \\
25 & $1.005 \pm 0.029$ & $3.5 \pm 0.92$ \\
50 & $0.912 \pm 0.025^{\mathrm{a}, \mathrm{b}}$ & $12.7 \pm 3.29^{\mathrm{a}, \mathrm{b}}$ \\
100 & $0.677 \pm 0.036^{\mathrm{a}-\mathrm{c}}$ & $35.2 \pm 4.21^{\mathrm{a}-\mathrm{c}}$ \\
200 & $0.532 \pm 0.019^{\mathrm{a}-\mathrm{d}}$ & $49.1 \pm 3.75^{\mathrm{a}-\mathrm{d}}$ \\
400 & $0.328 \pm 0.016^{\mathrm{a}-\mathrm{e}}$ & $68.3 \pm 2.87^{\mathrm{a}-\mathrm{e}}$ \\
\hline
\end{tabular}

${ }^{\mathrm{a}} \mathrm{P}<0.01$ vs. control group, ${ }^{\mathrm{b}} \mathrm{P}<0.01$ vs. $25 \mu \mathrm{mol} / 1, \quad{ }^{\mathrm{c}} \mathrm{P}<0.01$ vs. $50 \mu \mathrm{mol} / 1,{ }^{\mathrm{d}} \mathrm{P}<0.01$ vs. $100 \mu \mathrm{mol} / 1,{ }^{\mathrm{e}} \mathrm{P}<0.01$ vs. $200 \mu \mathrm{mol} / 1$.

for $48 \mathrm{~h}$ at $37^{\circ} \mathrm{C}$. Control cells were treated with DMSO. Cells were collected and washed twice with PBS. A total of $5 \times 10^{5}$ cells $/ \mathrm{ml}$ were re-suspended in $400 \mu \mathrm{l}$ binding buffer with $5 \mu \mathrm{l}$ Annexin V-fluorescein isothiocyanate (FITC) and $1 \mu \mathrm{l} \mathrm{PI}(100 \mu \mathrm{g} / \mathrm{ml})$ in the dark. Following incubation at $37^{\circ} \mathrm{C}$ for $15 \mathrm{~min}$, cell apoptosis was detected by flow cytometry (FACSCalibur; BD Biosciences, Franklin Lakes, NJ, USA) and was analyzed using CellQuest 3.3 software (BD Biosciences).

Western blot analysis. Cells were lysed with radioimmunoprecipitation assay lysate (Beyotime Institute of Biotechnology) to extract the total protein. The concentration of total protein was then quantitated using a BCA protein assay kit (Beyotime Institute of Biotechnology). Following this, $40 \mu \mathrm{g}$ protein was loaded and separated on $12 \%$ SDS-PAGE and transferred to nitrocellulose membranes. The membranes were blocked with $5 \%$ non-fat milk for $1 \mathrm{~h}$ at $37^{\circ} \mathrm{C}$ and probed with specific primary antibodies against COX-2, Bcl-2, Bax, VEGF, cleaved-caspase-3, pro-caspase-3, PTEN and $\beta$-actin at $4^{\circ} \mathrm{C}$ overnight. Subsequently, the membranes were incubated at $37^{\circ} \mathrm{C}$ with their corresponding secondary antibodies for $1 \mathrm{~h}$. Target bands were visualized using an enhanced chemiluminescence solution (Qihai Biotec, Shanghai, China) and the Gel-Pro-Analyzer software (Bethesda, MD, USA) was employed to measure relative band intensities. Each target protein was normalized to the corresponding $\beta$-actin band. Protein from untreated cells were loaded onto each gel for comparison.

Statistical analysis. Statistical analysis was performed using GraphPad Prism software (version 5.0; GraphPad Software, Inc., La Jolla, CA, USA). Data are presented as the mean \pm standard deviation $(n \geq 3)$. One way analysis of variance followed by Tukey's multiple comparisons test was used to compare differences between groups. $\mathrm{P}<0.05$ was considered to indicate a statistically significant difference.

\section{Results}

Nimesulide inhibits proliferation of PANC-1 cells. The results of MTT assays indicated that the inhibitory effect of nimesulide on the proliferation of PANC-1 cells could be observed from a dose of 50-400 $\mu \mathrm{mol} / 1$ (Table I). The inhibitory effect occurred in a concentration-dependent manner. 
A

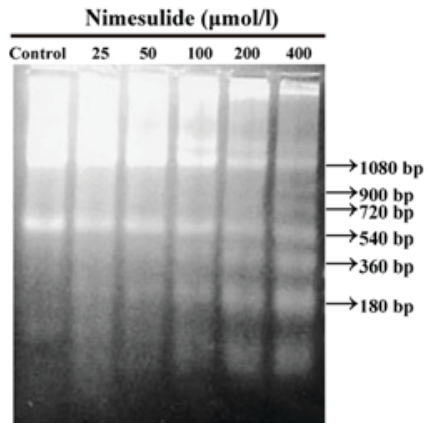

E

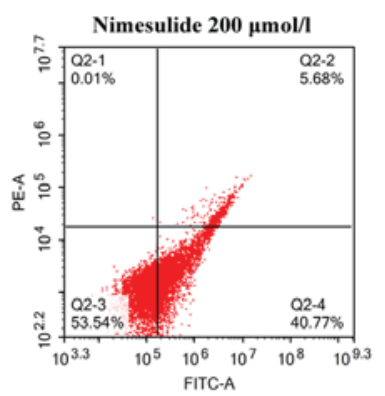

B

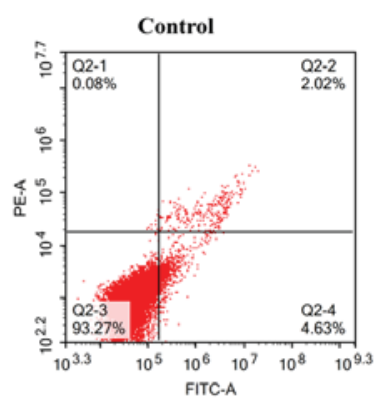

$\mathrm{F}$

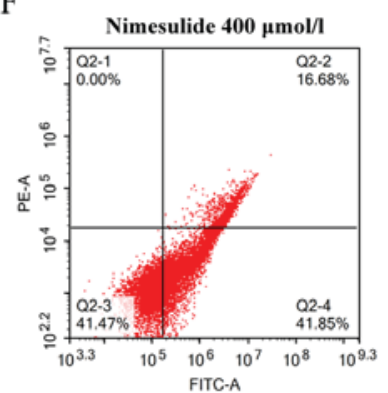

C

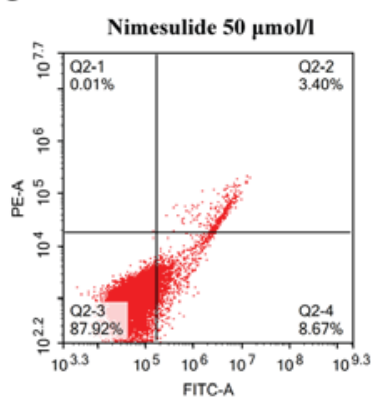

G

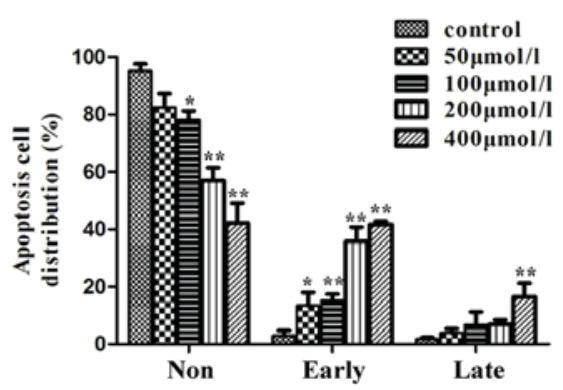

Figure 1. Apoptosis analysis of PANC-1 cells following treatment with nimesulide. (A) DNA laddering revealed the presence of apoptotic DNA fragmentation following treatment with different concentrations of nimesulide $(0,25,50,100,200$ and $400 \mu$ mol/l) for $48 \mathrm{~h}$. PANC-1 cells were treated with nimesulide at a concentration of (B) 0, (C) 50, (D) 100, (E) 200 and (F) $400 \mu \mathrm{mol} / 1$ for $48 \mathrm{~h}$ and the apoptosis rate was determined by flow cytometry with Annexin V-fluorescein isothiocyanate/propidium iodide double dye assay. $(\mathrm{G})$ Flow cytometry results were analyzed quantitatively. Data are presented as the mean \pm standard deviation ( $\mathrm{n}=3)$. ${ }^{*} \mathrm{P}<0.05$ and ${ }^{* *} \mathrm{P}<0.01$ vs. the control group.

Nimesulide induces apoptosis of PANC-1 cells. DNA laddering demonstrated that characteristics of apoptosis occurred following a $48 \mathrm{~h}$ treatment with nimesulide from the concentration of 50-400 $\mu \mathrm{mol} / 1$ (Fig. 1A). The results of flow cytometry demonstrated that treatment with 200 and $400 \mu \mathrm{mol} / \mathrm{l} \mathrm{nimesu}-$ lide for $48 \mathrm{~h}$ significantly increased early apoptosis of PANC-1 cells, compared with control cells (Fig. 1B-G). The above results indicated that nimesulide could induce early and late apoptosis of PANC-1 cells. To further investigate the mechanisms underlying nimesulide-induced apoptosis in PANC-1 cells, downstream mediators in the apoptotic cascade were analyzed by western blotting (Fig. 2). Following treatment with 100 and $200 \mu \mathrm{mol} / 1$ nimesulide for $48 \mathrm{~h}$, increased expressions of Bax and cleaved caspase-3 was observed, respectively. Expression of pro-caspase- 3 and $\mathrm{Bcl}-2$ decreased following treatment with 100 and 50-200 $\mu \mathrm{mol} / 1$ nimesulide, respectively.

Nimesulide decreases expression of COX-2 in PANC-1 cells. Protein expression of COX-2 in PANC cells was downregulated following treatment with nimesulide. Following treatment with 100, 200 or $400 \mu \mathrm{mol} / 1$ nimesulide for $48 \mathrm{~h}$, cells demonstrated significantly lower expression of COX-2 protein compared with the untreated control cells (Fig. 3). Therefore, nimesulide suppressed expression of COX-2 in PANC-1 cells. The above results suggest the nimesulide may function as a COX-2 inhibitor in pancreatic cancer cells.

Nimesulide enhances expression of PTEN and downregulates expression of VEGF in PANC-1 cells. To elucidate the mechanism underlying the anti-proliferative and pro-apoptotic effects of nimesulide, protein expression of PTEN and VEGF were determined (Fig. 4). Following treatment with $400 \mu \mathrm{mol} / \mathrm{l}$ nimesulide for $48 \mathrm{~h}$, expression of PTEN increased, compared with the control group. Expression of VEGF decreased significantly following treatment with 100 and $400 \mu \mathrm{mol} / 1$ nimesulide. These results indicated that PTEN and VEGF may be involved in the anti-proliferative and pro-apoptotic effects of nimesulide in PANC cells. However, the expression of VEGF was not significant following treatment with $200 \mu \mathrm{mol} / 1$ nimesulide. This may have been due to experimental error, but further study is required for clarification.

\section{Discussion}

Pancreatic cancer is an aggressive malignant disease and is one of the tumor types that is intrinsically resistant to chemotherapy $(22,23)$. Apoptosis, also known as programmed cell death, serves a role in maintaining homeostasis of both normal and neoplastic cells (24). Suppression of cancer cell apoptosis is considered to contribute to development and progression of carcinomas by triggering gene mutations and promoting resistance to immune-based cytotoxicity (25). Previous studies have demonstrated that nimesulide promotes apoptosis of KOSC-2 oral squamous carcinoma cells (26). Nimesulide can also induce apoptosis by inactivating the Janus kinase 2/signal transducer and activator of transcription 3 pathway in Eca-109 cells (21). Consistent with the aforementioned studies, the present study demonstrated that nimesulide can induce apoptosis of PANC-1 cells as demonstrated by DNA laddering and Annexin V-FITC/PI experiments. Bax is a pro-apoptotic protein, whereas Bcl-2 is an anti-apoptotic protein (27). It has been previously demonstrated that downregulation of $\mathrm{Bcl}-2$ 


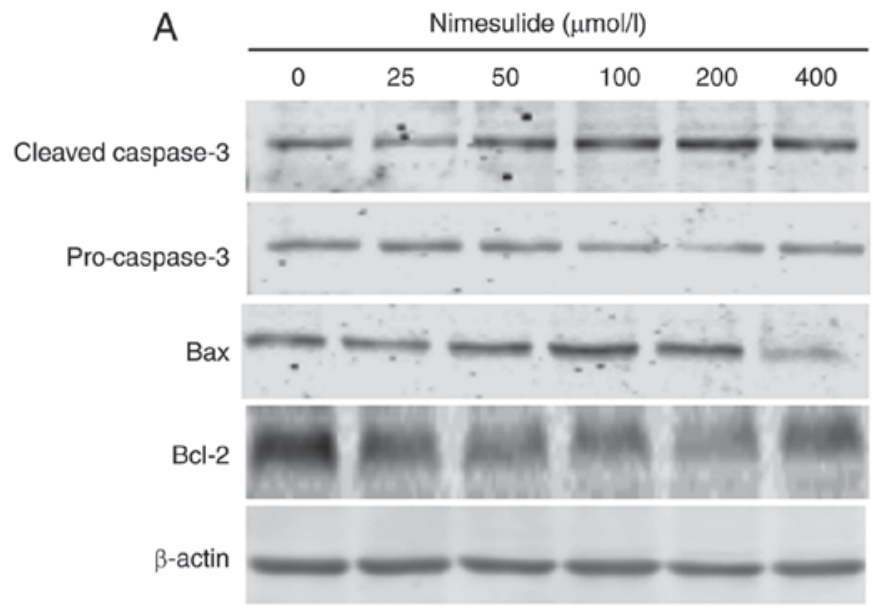

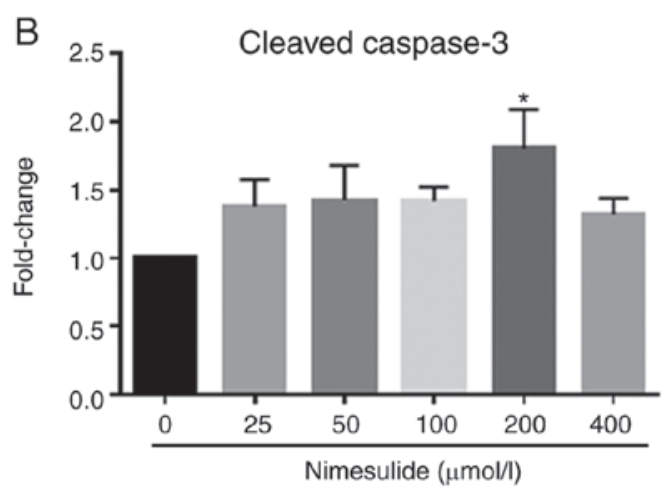

D

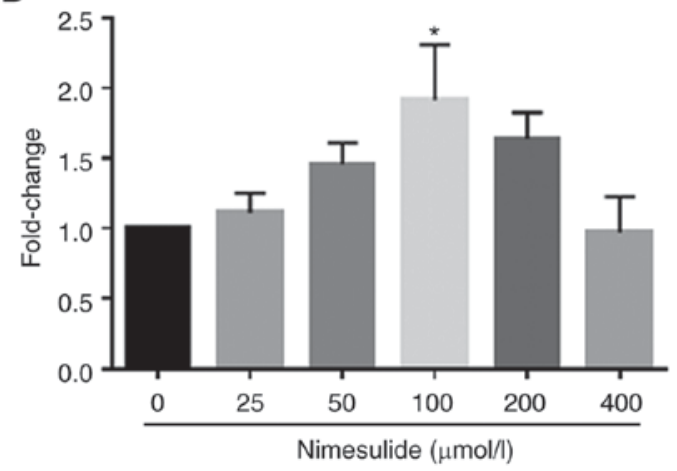

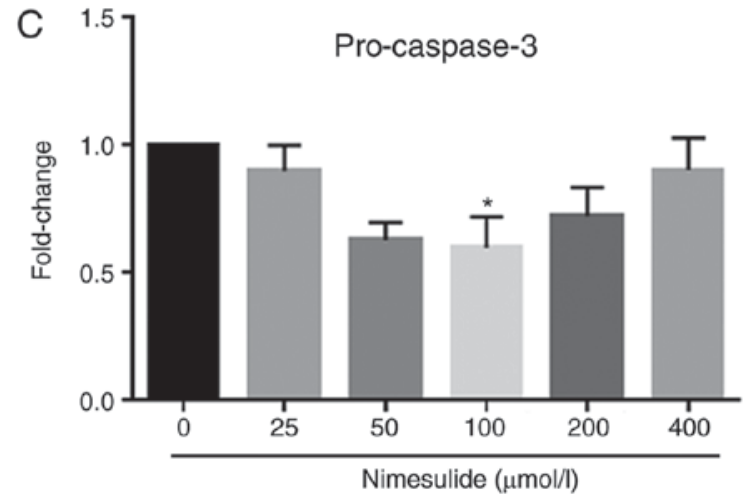

E

$\mathrm{Bcl}-2$

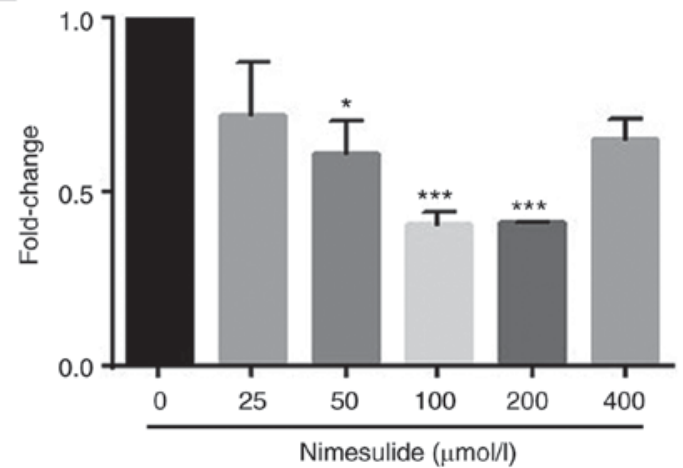

Figure 2. Effects of nimesulide on expression of cleaved-caspase-3, pro-caspase-3, Bax and Bcl-2 in PANC-1 cells. (A) PANC-1 cells were treated with different concentrations of nimesulide $(0,25,50,100,200$ and $400 \mu \mathrm{mol} / 1)$ for $48 \mathrm{~h}$ and protein expression was determined by western blotting. Expression of (B) cleaved caspase-3, (C) pro-caspase-3, (D) Bax and (E) Bcl-2 was analyzed. " $\mathrm{P}<0.05$ and ${ }^{* * * *} \mathrm{P}<0.001$ vs. the control group. Bax, Bcl-2 associated protein $\mathrm{X}$; Bcl-2, B-cell lymphoma 2.

enables oligomerized Bax to insert into the outer mitochondrial membrane and promote apoptosis (28). The present study demonstrated that nimesulide could decrease expression levels of Bcl-2 and increase expression levels of Bax in PANC-1 cells, which suggested that apoptosis induced by nimesulide treatment of PANC-1 cells may be due to the activation of mitochondrial apoptotic pathways.

It has been previously reported that PTEN can regulate angiogenesis of human pancreatic cancer cells and that it is a suppressor of pancreatic ductal adenocarcinoma $(29,30)$. Therefore, enhanced expression of PTEN in PANC-1 cells following treatment with nimesulide indicated a possible novel role of nimesulide in the treatment of pancreatic cancer in addition to inhibition of COX-2. The major substrate, with which PTEN interacts, is phosphatidylinositol $(3,4,5)$-trisphosphate, which is produced by the action of phosphoinositide-3-kinases (PI3Ks) (19). The $\mathrm{PI} 3 \mathrm{~K} / \mathrm{RAC}$-alpha serine/threonine-protein kinase (Akt) signaling pathway serves a role in the development of resistance to carcinoma therapy, and inhibition of the PI3K/Akt signaling pathway may suppress cancer cell growth and induce apoptosis in various cancer types (31-33). However, effects of upregulation of PTEN by nimesulide on PI3K/Akt signaling-mediated apoptosis of PANC-1 cells remains to be elucidated. Activation of peroxisome proliferator-activated receptor $\gamma$ in human pancreatic cancer cells has been 

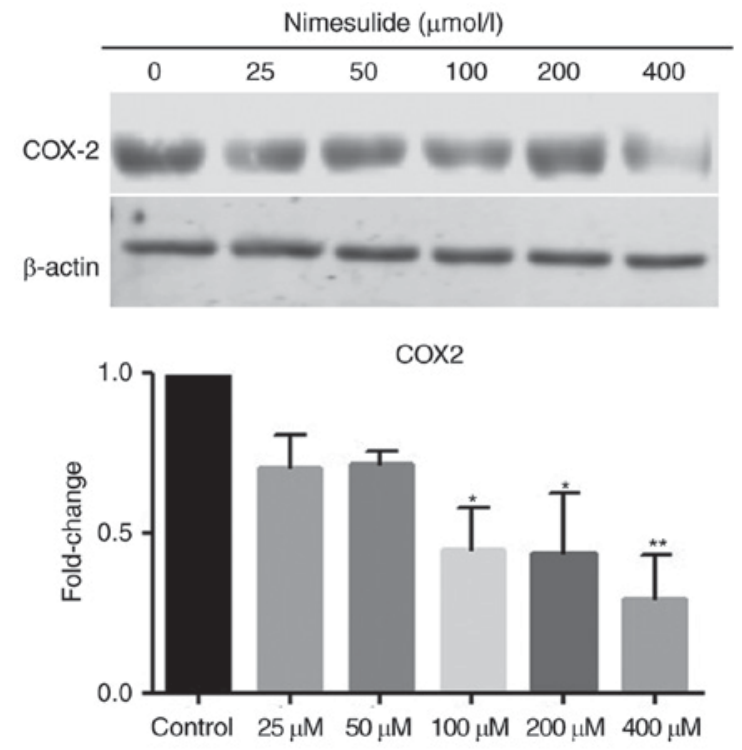

Figure 3. Effects of nimesulide on expression of COX-2 in PANC-1 cells. PANC-1 cells were treated with different concentrations of nimesulide $(0,25$, 50, 100, 200 and $400 \mu \mathrm{mol} / \mathrm{l})$ for $48 \mathrm{~h}$ and COX-2 expression was evaluated using western blot analysis. ${ }^{*} \mathrm{P}<0.05$ and ${ }^{* *} \mathrm{P}<0.01$ vs. the control group. COX-2, prostaglandin-endoperoxide synthase 2 .
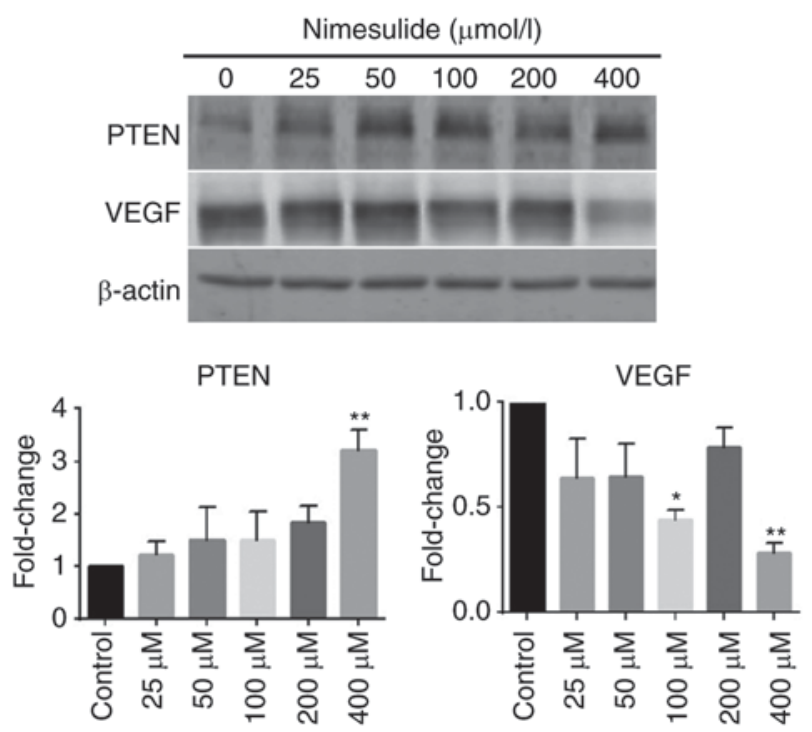

Figure 4. Effects of nimesulide on the expression of PTEN and VEGF in PANC-1 cells. PANC-1 cells were treated with different concentrations of nimesulide $(0,25,50,100,200$ and $400 \mu \mathrm{mol} / \mathrm{l})$ for $48 \mathrm{~h}$ and expression of PTEN and VEGF was evaluated using western blot analysis. Treatment with nimesulide increased the expression of PTEN and decreased the expression of VEGF. ${ }^{*} \mathrm{P}<0.05$ and ${ }^{* *} \mathrm{P}<0.01$ vs. the control group. PTEN, phosphatase and tensin homolog; VEGF, vascular endothelial growth factor.

demonstrated to be associated with enhanced expression of PTEN and apoptosis (34), which suggests that there may be a PI3K/Akt-independent mechanism underlying the anti-apoptotic and PTEN-enhancing effect of nimesulide in PANC-1 cells.

VEGF, a selective mitogen of vascular endothelial cells, serves a role in angiogenesis (35). In endothelial cells, PTEN antagonizes PI3K signalling, which mediates VEGF expression and angiogenesis (36). Overexpression of PI3K and
Akt could induce transcription of VEGF and promote the formation of new blood vessels (37). Furthermore, following inhibition of PTEN, PI3K/Akt is activated, resulting in cell division, increased cell volume, apoptosis and tumor angiogenesis $(38,39)$. In the present study, the results indicated that nimesulide increased PTEN expression but decreased expression levels of VEGF, which suggested that nimesulide may inhibit angiogenesis of PANC-1 cells.

The carcinogenic role of COX-2 overexpression has been demonstrated in a number of human malignancies, including pancreatic cancer (40). Overexpression of COX-2 is associated with tumor aggressiveness and growth in cancer biology $(41,42)$. However, a previous study reported that nimesulide induces apoptosis in MIA PaCa- 2 cells (no COX-2 protein expression) and $\mathrm{BxPC}-3$ cells (high $\mathrm{COX}-2$ protein expression), which suggested that the effect of nimesulide may be independent of COX-2 protein expression (16). In the present study, the results demonstrated that nimesulide decreases the expression of COX-2 and increases the expression of PTEN, but also results in inhibition of proliferation of PANC-1 cells. Furthermore, COX-2 positively regulates Akt signalling by suppressing the activity of PTEN (43) and prostaglandin E2 (44). In a previous study, In cells transformed with erb-b2 receptor tyrosine kinase 2, the activation or inhibition of mitogen-activated protein kinase and PI3K/Akt cascades resulted in the up- and downregulation of COX-2, respectively (45). In summary, the anti-cancer effect of nimesulide in PANC-1 cells may be associated with the interaction between PTEN and COX-2.

In conclusion, the results of the present study demonstrated that nimesulide induced an anti-cancer effect on PANC-1 cells. Specifically, nimesulide inhibited proliferation and promoted apoptosis of PANC-1 cells via enhancement of expression of PTEN. Furthermore, the results of the present study suggest that nimesulide may prevent tumor angiogenesis by inhibiting expression of VEGF. The regulatory effects of nimesulide on PANC-1 cells may be associated with interactions between PTEN and COX-2 through the PI3K/Akt signalling pathway. However, this hypothesis requires further investigation.

\section{Acknowledgements}

Not applicable.

\section{Funding}

The present study was supported by grants obtained from the National Natural Science Foundation of China (grant no. 81772232), a project funded by Zhejiang Medical College Youth Dr. start-up (grant. no. 2015B07), a project funded by the Education Department Foundation of Zhejiang Province (grant no. Y201636954) and a project funded by Zhejiang Medicine Health Science and Technology Funding (grant no. 2013KYAO47).

\section{Availability of data and materials}

The datasets used and/or analyzed during the current study are available from the corresponding author on reasonable request. 


\section{Authors' contributions}

YC and AS conceived and designed the study. MC, TW and YC performed the experiments. YC wrote the paper. YC, MC and TW reviewed and edited the manuscript. All authors read and approved the manuscript and agree to be accountable for all aspects of the research in ensuring that the accuracy or integrity of any part of the work are appropriately investigated and resolved.

\section{Ethics approval and consent to participate}

Not applicable.

\section{Consent for publication}

Not applicable.

\section{Competing interests}

The authors declare that they have no competing interests.

\section{References}

1. Siegel R, Naishadham D and Jemal A: Cancer statistics for Hispanics/Latinos, 2012. CA Cancer J Clin 62: 283-298, 2012.

2. He Y, Zheng R, Li D, Zeng H, Zhang S and Chen W: Pancreatic cancer incidence and mortality patterns in China, 2011. Chin J Cancer Res 27: 29-37, 2015.

3. Chen W, Zheng R, Baade PD, Zhang S, Zeng H, Bray F, Jemal A, Yu XQ and He J: Cancer statistics in China, 2015. CA Cancer J Clin 66: 115-132, 2016.

4. Wei X, Wang W, Wang L, Zhang Y, Zhang X, Chen M, Wang F, Yu J, Ma Y and Sun G: MicroRNA-21 induces 5-fluorouracil resistance in human pancreatic cancer cells by regulating PTEN and PDCD4. Cancer Med 5: 693-702, 2016.

5. Neoptolemos JP, Dunn JA, Stocken DD, Almond J, Link K, Beger H, Bassi C, Falconi M, Pederzoli P, Dervenis C, et al: Adjuvant chemoradiotherapy and chemotherapy in resectable pancreatic cancer: A randomised controlled trial. Lancet 358: $1576-1585,2001$.

6. Van Laethem JL,Hammel P, Mornex F, Azria D, Van Tienhoven G, Vergauwe P, Peeters M, Polus M, Praet M, Mauer M, et al: Adjuvant gemcitabine alone versus gemcitabine-based chemoradiotherapy after curative resection for pancreatic cancer: A randomized EORTC-40013-22012/FFCD-9203/GERCOR phase II study. J Clin Oncol 28: 4450-4456, 2010.

7. Moore MJ, Goldstein D, Hamm J, Figer A, Hecht JR, Gallinger S, Au HJ, Murawa P, Walde D, Wolff RA, et al: Erlotinib plus gemcitabine compared with gemcitabine alone in patients with advanced pancreatic cancer: A phase III trial of the National Cancer Institute of Canada Clinical Trials Group. J Clin Oncol 25: 1960-1966, 2007.

8. Sutton JM and Abbott DE: Neoadjuvant therapy for pancreas cancer: Past lessons and future therapies. World J Gastroenterol 20: 15564-15579, 2014.

9. Kamangar F, Dores GM and Anderson WF: Patterns of cancer incidence, mortality, and prevalence across five continents: Defining priorities to reduce cancer disparities in different geographic regions of the world. J Clin Oncol 24: 2137-2150, 2006

10. Hidalgo M: Pancreatic cancer. N Engl J Med 362: 1605-1617, 2010.

11. Miglietta A, Toselli M, Ravarino N, Vencia W, Chiecchio A, Bozzo F, Motta M, Torchio B and Bocca C: COX-2 expression in human breast carcinomas: Correlation with clinicopathological features and prognostic molecular markers. Expert Opin Ther Targets 14: 655-664, 2010.

12. Richardsen E, Uglehus RD, Due J, Busch C and Busund LT: COX-2 is overexpressed in primary prostate cancer with metastatic potential and may predict survival. A comparison study between COX-2, TGF-beta, IL-10 and Ki67. Cancer Epidemiol 34: 316-322, 2010.
13. Chang J, Xue M, Yang S, Yao B, Zhang B, Chen X, Pozzi A and Zhang MZ: Inhibition of $11 \beta$-Hydroxysteroid Dehydrogenase type II suppresses lung carcinogenesis by blocking tumor COX-2 expression as well as the ERK and mTOR signaling pathways. PLoS One 10: e0127030, 2015.

14. Jakstaite A, Maziukiene A, Silkuniene G, Kmieliute K, Gulbinas A and Dambrauskas Z: HuR mediated post-transcriptional regulation as a new potential adjuvant therapeutic target in chemotherapy for pancreatic cancer. World J Gastroenterol 21: 13004-13019, 2015.

15. Li S, Gu Z, Xiao Z, Zhou T, Li J and Sun K: Anti-tumor effect and mechanism of cyclooxygenase- 2 inhibitor through matrix metalloproteinase 14 pathway in PANC-1 cells. Int J Clin Exp Pathol 8: 1737-1742, 2015.

16. Eibl G, Reber HA, Wente MN and Hines OJ: The selective cyclooxygenase-2 inhibitor nimesulide induces apoptosis in pancreatic cancer cells independent of COX-2. Pancreas 26: 33-41, 2003.

17. Funahashi H, Satake M, Dawson D, Huynh NA, Reber HA, Hines OJ and Eibl G: Delayed progression of pancreatic intraepithelial neoplasia in a conditional Kras(G12D) mouse model by a selective cyclooxygenase-2 inhibitor. Cancer Res 67: 7068-7071, 2007.

18. Eibl G, Takata Y, Boros LG, Liu J, Okada Y, Reber HA and Hines OJ: Growth stimulation of COX-2-negative pancreatic cancer by a selective COX-2 inhibitor. Cancer Res 65: 982-990, 2005.

19. Kishimoto H, Hamada K, Saunders M, Backman S, Sasaki T, Nakano T, Mak TW and Suzuki A: Physiological functions of Pten in mouse tissues. Cell Struct Funct 28: 11-21, 2003

20. Dang Q, Song W, Xu D, Ma Y, Li F, Zeng J, Zhu G, Wang X, Chang LS, He D and Li L: Kaempferol suppresses bladder cancer tumor growth by inhibiting cell proliferation and inducing apoptosis. Mol Carcinog 54: 831-840, 2015.

21. Liu JR, Wu WJ, Liu SX, Zuo LF, Wang Y, Yang JZ and Nan YM: Nimesulide inhibits the growth of human esophageal carcinoma cells by inactivating the JAK2/STAT3 pathway. Pathol Res Pract 211: 426-434, 2015.

22. Siegel R, Naishadham D and Jemal A: Cancer statistics, 2012. CA Cancer J Clin 62: 10-29, 2012.

23. Neoptolemos JP, Stocken DD, Bassi C, Ghaneh P, Cunningham D, Goldstein D, Padbury R, Moore MJ, Gallinger S, Mariette C, et al: Adjuvant chemotherapy with fluorouracil plus folinic acid vs gemcitabine following pancreatic cancer resection: A randomized controlled trial. JAMA 304: 1073-1081, 2010.

24. Su M, Mei Y and Sinha S: Role of the crosstalk between autophagy and apoptosis in cancer. J Oncol 2013: 102735, 2013.

25. Satoh K, Kaneko K, Hirota M, Masamune A, Satoh A and Shimosegawa T: Expression of survivin is correlated with cancer cell apoptosis and is involved in the development of human pancreatic duct cell tumors. Cancer 92: 271-278, 2001.

26. Yuan Z, Chen D, Chen X and Wei Y: Novel combination of Vincristine and COX-2 Inhibitor Nimesulide provides synergistic anti-proliferative and pro-apoptotic effects in KOSC-2 oral squamous carcinoma cells. Int J Clin Exp Me 9: 877-887, 2016.

27. Kumar S, Eroglu E, Rd SJ, Stokes JA III, Scissum-Gunn K, Saldanha SN, Singh UP, Manne U, Ponnazhagan S and Mishra MK: Resveratrol induces mitochondria-mediated, caspase-independent apoptosis in murine prostate cancer cells. Oncotarget 8: 20895-20908, 2017.

28. Bhola PD and Letai A: Mitochondria-judges and executioners of cell death sentences. Mol Cell 61: 695-704, 2016.

29. Ma J, Sawai H, Ochi N, Matsuo Y, Xu D, Yasuda A, Takahashi H, Wakasugi T and Takeyama H: PTEN regulates angiogenesis through PI3K/Akt/VEGF signaling pathway in human pancreatic cancer cells. Mol Cell Biochem 331: 161-171, 2009.

30. Ying H, Elpek KG, Vinjamoori A, Zimmerman SM, Chu GC, Yan H, Fletcher-Sananikone E, Zhang H, Liu Y, Wang W, et al: PTEN is a major tumor suppressor in pancreatic ductal adenocarcinoma and regulates an NF- $\kappa \mathrm{B}$-cytokine network. Cancer Discov 1: 158-169, 2011.

31. Cheng TC, Lai CS, Chung MC, Kalyanam N, Majeed M, Ho CT, Ho YS and Pan MH: Potent anti-cancer effect of 3'-hydroxypterostilbene in human colon xenograft tumors. PLoS One 9: e111814, 2014.

32. Gowda R, Madhunapantula SV, Desai D, Amin S and Robertson GP: Simultaneous targeting of COX-2 and AKT using selenocoxib-1-GSH to inhibit melanoma. Mol Cancer Ther 12: 3-15, 2013.

33. Hodgson MC, Deryugina EI, Suarez E, Lopez SM, Lin D, Xue H, Gorlov IP, Wang Y and Agoulnik IU: INPP4B suppresses prostate cancer cell invasion. Cell Commun Signal 12: 61, 2014. 
34. Farrow B and Evers BM: Activation of PPARgamma increases PTEN expression in pancreatic cancer cells. Biochem Biophys Res Commun 301: 50-53, 2003.

35. Liang D, Chang JR, Chin AJ, Smith A, Kelly C, Weinberg ES and Ge R: The role of vascular endothelial growth factor (VEGF) in vasculogenesis, angiogenesis, and hematopoiesis in zebrafish development. Mech Dev 108: 29-43, 2001.

36. Wen S, Stolarov J, Myers MP, Su JD, Wigler MH, Tonks NK and Durden DL: PTEN controls tumor-induced angiogenesis. Proc Natl Acad Sci USA 98: 4622-4627, 2001.

37. An $X, \operatorname{Lv} H$, Tian $J, H e X$ and Ling $N$ : Role of the PTEN/PI3K/VEGF pathway in the development of Kawasaki disease. Exp Ther Med 11: 1318-1322, 2016.

38. Carracedo A and Pandolfi PP: The PTEN-PI3K pathway: Of feedbacks and cross-talks. Oncogene 27: 5527-5541, 2008.

39. Carnero A, Blanco-Aparicio C, Renner O, Link W and Leal JF: The PTEN/PI3K/AKT signalling pathway in cancer, therapeutic implications. Curr Cancer Drug Targets 8: 187-198, 2008.

40. Song Z, Bhagat G, Quante M, Baik GH, Marrache F, Tu SP Zhao CM, Chen D, Dannenberg AJ and Wang TC: Potential carcinogenic effects of cigarette smoke and Swedish moist snuff on pancreas: A study using a transgenic mouse model of chronic pancreatitis. Lab Invest 90: 426-435, 2010.
41. Juuti A, Louhimo J, Nordling S, Ristimäki A and Haglund C: Cyclooxygenase-2 expression correlates with poor prognosis in pancreatic cancer. J Clin Pathol 59: 382-386, 2006.

42. Ristimäki A, Sivula A, Lundin J, Lundin M, Salminen T, Haglund C, Joensuu $\mathrm{H}$ and Isola J: Prognostic significance of elevated cyclooxygenase-2 expression in breast cancer. Cancer Res 62: 632-635, 2002.

43. Li CJ, Chang JK, Wang GJ and Ho ML: Constitutively expressed COX-2 in osteoblasts positively regulates Akt signal transduction via suppression of PTEN activity. Bone 48: 286-297, 2011.

44. Vo BT, Morton D Jr, Komaragiri S, Millena AC, Leath C and Khan SA: TGF- $\beta$ effects on prostate cancer cell migration and invasion are mediated by PGE2 through activation of PI3K/AKT/mTOR pathway. Endocrinology 154: 1768-1779, 2013.

45. Subbaramaiah K, Norton L, Gerald W and Dannenberg AJ: Cyclooxygenase- 2 is overexpressed in HER-2/neu-positive breast cancer: Evidence for involvement of AP-1 and PEA3. J Biol Chem 277: 18649-18657, 2002. 